\title{
Spatio-Temporal Implications of Inadequate Water and Sanitation on Residents of Ijora-Badia Area of Lagos State, Nigeria
}

\author{
Yussuf Lukeman ${ }^{1}$, Bako, A. I. ${ }^{2}$, Omole, F. K. ${ }^{3}$, Nwokoro, I. I. C. ${ }^{1} \&$ Olajuyigbe, A. E. ${ }^{3}$ \\ ${ }^{1}$ Department of Urban and Regional Planning, University of Lagos, Nigeria \\ ${ }^{2}$ Department of Urban and Regional Planning, University of Ilorin, Nigeria \\ ${ }^{3}$ Department of Urban and Regional Planning, the Federal University of Technology, Akure, Nigeria \\ Correspondence: Omole, F. K., Department of Urban and Regional Planning, the Federal University of \\ Technology, P.M.B 704, Akure, Nigeria. E-mail: fkyomole@yahoo.co.uk
}

Received: March 3, 2014 Accepted: March 18, 2014 Online Published: November 23, 2014

doi:10.5539/eer.v4n3p119 URL: http://dx.doi.org/10.5539/eer.v4n3p119

\begin{abstract}
In recent times, it has been proofed that industrial revolution, urbanization, inadequate provision of facilities, poor urban management and poverty were the determinant of environmental condition of city dwellers. In this paper, the sanitary condition of the environment of residents of Ijora Badia was investigated. Some of the sanitary conditions data involving sources of drinking water, sources of cooking, method of waste disposal, types of toilet facility, drainage system and road conditions were collected through questionnaires, personal interview, direct observation and focus group discussion. The research population was based on the total number of existing buildings from which the total numbers of household head were determined and $5 \%$ of the total household head population was taken for the interview. Findings reveal that $65.5 \%$ of the residence sources of drinking water is through water vendor which has aggravated the water borne diseases, $93.1 \%$ of residence sources of cooking is stove which cause respiratory disease among the households. The paper suggests among other things that all stakeholders in the built environment should see to the welfare and provision of environmental facilities in order to make life comfortable and functional for the slum dwellers.
\end{abstract}

Keywords: environmental condition, development, facility, poverty and slum

\section{Introduction}

In Nigeria like in other developing countries, poor sanitation in various cities pose population health hazard through pollution (air, water and noise). Disposal and treatment of sewage is available for less than $2 \%$ of the population as the case is in Nigeria (UNICEF, 1999). Human excreta pose serious threat to the environment as well as public health, if not properly handled. Human excreta contain pathogen such as bacteria, viruses, protozoa, and helminthes, which lead to a range of infection in humans such as dysentery, diarrhea, and cholera among others. Uncontrolled disposal of excreta in soil and water can lead to an overload of organic compounds and nutrients in the environment resulting in the loss of plant, animals, and human lives.

Brundtland, (2003) identified environmental risks to include inadequate access to safe drinking water, poor hygiene and sanitation, inadequate water resources management, air pollution, chemical hazards, and unintentional injuries. According to him, estimated 1.1 billion people lacked access to an improved water source in the year 2000. In year 2003, around 2.4 billion people lack access to any type of improved sanitation facilities, while air pollution becomes a serious risk factor for respiratory disease and major contribution to ill-health among children around the world.

Along this line, Egunjobi, (1986) posited that a lot of people die every day from various diseases caused by their inadequate shelter or lack of access to such basic services as clean water or sanitary excreta disposal. Available global evidence in the literature including the works of Smith et al. (1999) and that of Tibaijuka (2003) suggest that lack of access to clean water and sanitation and indoor air pollution are principal risk factors of illness and death, mainly affecting children and women in poor families.

The public worldwide has now become acutely aware that health and life sustainability are put at risk with the present level of poor sanitary conditions of the environment. Some of the waste dumped around proved extremely toxic and hazardous, which through their indiscriminate dumping, have brought about the death of 
livestock, environmental pollutions, and an increasing number of incidents that have caused ill-health and epidemic of diseases like malaria and respiratory diseases. A potentially more serious risk to human health is the contamination of source of water supply (Adeola, 1996).

In recent times, the residents of Ijora-Badia (the study area) have been faced with many environmental conditions problems such as poor water supply, inadequate toilet facilities, poor drainage and sanitation conditions. The aftermath of the shortfall in the provision of some of these facilities has resulted in epidemic and deadly diseases such as diarrhea, cholera, typhoid among others. In view of these, this paper examines the environmental conditions of the residents of Ijora-Badia in Lagos Nigeria.

\section{The Study Area}

Ijora- Badia is one of the blighted area identified by the UNDP which was also validated by the consulting firm SNC-Lavalin employed by the Lagos State Government in the World Bank assisted Infrastructure Upgrading programme for the metropolitan Lagos (UNDP, 1997).

The specific study area is Ijora-Badia, one of the suburbs in the Apapa Local Government of Lagos State and it is located in the Southern fringe of the Lagos Metropolitan area. It is situated at the interaction point of the geographical latitude $3^{\circ} 23^{\prime}$ and longitude $4^{\circ} 22^{\prime}$. It is bounded in the North by the Lagos Badagry expressway link bridge into the National Theatre. A railroad to Apapa forms the Eastern boundary. The South is bounded by Ajegunle another low-income residential suburb.

\section{Literature Issues}

Extreme inequality and idleness lead people to anti-social behavior, which is more pronounced in the slum area.

Slums are the places where all the evils come together, where peace and security is elusive and where young people cannot be protected. Tibaijuka, (2003) is of the view that deteriorating situation which potentially threatened the security and increases pressures on immigration to rich countries should be addressed. He observed that some slums were now as large as cities. The Kibera district in Nairobi which was classed as the largest slum in the world has as many as 600,000 people. The Dharavi area of Mumbai and the Orangi district of Karachi have only slightly fewer people, while the Ashaiman slum is now larger than the city of Tema in Ghana, around which it grew.

Other cities, such as Dhaka in Bangladesh, have several hundred small slums or squatter settlements, which have no access to services and are liable to be moved on at short notice. The world is entering a significant stage, say the report's authors. Over the next 30 years, the urban population in the developing world will double to about 4 billion people, at the rate of about 70 million a year. Rural populations will barely increase and begin to decline after 2020." The authors also predicted that three quarters of the world's anticipated population growth would take place in relatively small cities with populations of between 1 million and 5 million. The report found that the world's urban population had increased by $36 \%$ in the 1990 s, and that city authorities had been unable or unwilling to keep up. Slums are the product of failed policies, bad governance, corruption and a lack of political will, the report says. Very few countries have recognized this critical situation and very little effort is going into providing jobs or services." But the authors roundly blamed laissez-faire globalization and "neo-liberal" economic policies imposed on poor countries by global institutions such as the International Monetary Fund and the World Trade Organisation for much of the damage caused to cities over the past 20 years.

The authors say people are encouraged to move to the cities by factors including the privatization of public services, job losses, and the removal of subsidies and tax breaks from key industries. Such effects, they say, increase inequality, and make sure that those who move to the cities remain in deep poverty. One of the few direct benefits that slum dwellers have gained from globalization is greater access to aid agencies, the report says. But the very limited advantages are outweighed by a truly formidable array of disadvantages so many, in fact, that some governments might be excused for not wishing to take part at all in globalization if they have the welfare of the urban poor at heart. In a form of colonialisation that is probably more stringent than the original, many developing countries have become suppliers of raw commodities to the world, and fall further and further behind. The authors conclude that as cities have become a dumping ground for people working in unskilled, unprotected and low-wage industries and trade the slums of the developing worlds well.

Innocent, (2009) in his study on the Millennium Development Goal on Slum Eradication in River state, stated that the urban crisis in Nigeria is not only manifested in the acute shortage of dwelling unit which has resulted in overcrowding, high rents, and slum settlements. There is also the inadequacy, both in terms of quality and quantity of basic infrastructural facilities and social services such as pipe-born water, electricity, roads, schools and health institutions. It is also portrayed by the gradual breakdown of the urban economic way of life which is 
reflected in rising unemployment, diminishing incomes and poverty especially among the less privileged.

\section{Methodology}

In order to ensure that this research work achieves its purpose, the study embraces both primary and secondary sources of information. These were obtained from the field through the use of research instrument such as administration of questionnaires, personal interviews, observations and focus group discussion. Secondary information was collected from reports, (published and unpublished sources), textbooks, journals, file of government agencies and parastatals. These include the National Population Commission, the local government, and on the Internet, among many others.

There are 539 residential buildings in Ijora-Badia, Lagos (Tenament Rate Department Apapa Local Government, 2011). It has an average of minimum 7 households in a building, being a high residential area of metropolitan Lagos, which is in accordance with the National Population Commission (NPC) information of 2006. Since, the minimum average households per building is 7 households, the targeted population household in the study area translate to $539 \times 7=$ three thousand seven hundred and seventy three $(3,773)$ households. The targeted household population of this study is 3,773 and the sample size is $5 \%$ of the targeted household population which translate to one hundred and eighty nine (189) and this becomes the total number of questionnaires administered for the study. In each district in the study area, 5\% sample size was considered reasonable for this study because of the homogeneous characteristics that was peculiar to the residents in the study area.

The research adopts multi stage sampling technique in the research procedure. First stage is the delineation and dividing Ijora Badia into three districts namely Ijora Badia West, Ijora Badia central, and Ijora Badia East (Onyeche, 2011). Second stage is the identification of the buildings in each of the district by systematic sampling technique. All buildings in each district were arranged serially, from which the sampled buildings were selected. The $3^{\text {rd }}$ building forms the nth term while every $3^{\text {rd }}$ building was sampled from each district.

A randomly sampling technique was adopted in the third stage for the selection of household head sampled. This sampling method was based on household size in selected residential building. Household with highest number of people was selected.

Finally, in each of the districts, questionnaires were administered systematically and randomly selection of household head on every $3^{\text {rd }}$ buildings in each district. The questionnaires were administered according to the number of buildings in the study area.

Table 1. Distribution of questionnaires within the district in the study area (Ijora-badia)

\begin{tabular}{ccc}
\hline Name of district & Buildings in each District & No. of Questionnaires Administered \\
\hline Ijora-badia West & 129 buildings & 45 \\
Ijora-badia Central & 230 buildings & 81 \\
Ijora-badia East & 180 buildings & 63 \\
Total & 539 Buildings & 189 \\
\hline
\end{tabular}

Source: Tenement Rate Department Apapa Local Government (2012).

\section{Research Findings and Discussion}

The environmental variables considered in this study focus on the sanitary conditions in the study area which comprises of sources of drinking water, types of toilet facility, sources of cooking, sources of energy, road conditions and types of drainage facility.

Table 2. Major source of drinking water

\begin{tabular}{lcr}
\hline Sources of Water & Frequency & Percent \\
\hline Borehole & 37 & 19.6 \\
Water vendor & 124 & 65.6 \\
Well & 3 & 1.6 \\
Pipe borne water & 25 & 13.2 \\
Total & 189 & 100.0 \\
\hline
\end{tabular}

Source: Authors' Field Survey, 2012. 
The sources of drinking water in the study area as shown in table 2 indicates that $19.6 \%$ of respondents sources of drinking water is borehole, $65.6 \%$ of respondents sources of drinking water is through water vendor, $1.6 \%$ of respondents sources of drinking water is through well and $13.2 \%$ of respondents sources of drinking water is from pipe-borne water. It is concluded that, majority of respondents sources of drinking water is through water vendor which very dangerous to the health of residents.

Table 3. Treatment of water before drinking

\begin{tabular}{lcc}
\hline Options & Frequency & Percentages \\
\hline Yes & 51 & 27.0 \\
No & 138 & 73.0 \\
Total & 189 & 100.0 \\
\hline
\end{tabular}

Source: Authors' Field Survey, 2012.

The responses of the residents in the study area shows that majority of the respondents do not treat their water before drinking. $27 \%$ of respondents treat their water before drinking while $73 \%$ of respondents do not treat the water before drinking. This made them to be vulnerable to water borne diseases.

Table 4. Distance of water from home

Source: Authors' Field Survey, 2012.

\begin{tabular}{lcc}
\hline Distance & Frequency & Percentages \\
\hline Less than $100 \mathrm{~m}$ & 165 & 87.3 \\
$200 \mathrm{~m}-500 \mathrm{~m}$ & 23 & 12.2 \\
$501 \mathrm{~m}-1 \mathrm{~km}$ & 1 & .5 \\
Total & 189 & 100.0 \\
\hline
\end{tabular}

The distance of water from various home shows that majority of respondents sources of water is not too far from their homes in the study area. Table 4 shows that $87.3 \%$ of respondents' distance of source of water from home is less than $100 \mathrm{~m}, 12.2 \%$ of respondents home is between $200 \mathrm{~m}-500 \mathrm{~m}$ to the source of water and only $0.5 \%$ respondents' home is between $501 \mathrm{~m}-1 \mathrm{~km}$ to the source of water. It can be inferred that majority of respondents source of water meet up with United Nations (UN) standard of less than $100 \mathrm{~m}$ to various homes. The water was found to be public borehole which was constructed by Local Government Chairman and the Lagos states Legislature representing Apapa consistency.

Table 5. Types of toilet facility

\begin{tabular}{lrr}
\hline Types of Toilet & Frequency & Percentages \\
\hline Pit latrine & 33 & 17.5 \\
Bush/open dump Drainage channel Water closet & 58 & 30.7 \\
& 72 & 38.0 \\
& 26 & 13.8 \\
Total & 189 & 100.0 \\
\hline
\end{tabular}

Source: Authors' Field Survey, 2012.

The types of toilet facilities in the study area as shown in table 5 show that $38.0 \%$ of the respondents used drainage canal, $17.5 \%$ made use of pit latrine, $30.7 \%$ used bush/ open dump site, while $13.8 \%$ of the respondents used water closet. This means that majority of the respondents used drainage canal as their toilet facilities. The canal was meant to collect water from the primary drainage and enter into the lagoon. This may also caused unnecessary odour which pollute the whole environment. 
Table 6. Sources of energy for Cooking

Source: Authors' Field Survey, 2012.

\begin{tabular}{lcc}
\hline Sources of energy & Frequency & Percentages \\
\hline Stove & 176 & 93.1 \\
Gas & 4 & 2.1 \\
Charcoal & 7 & 3.7 \\
Firewood & 2 & 1.1 \\
Total & 189 & 100.0 \\
\hline
\end{tabular}

Table 6 shows the sources of energy for cooking in the house by the respondents in study area shows that $93.1 \%$ of respondents' source of energy for cooking is stove, $2.1 \%$ used Gas, $3.7 \%$ of respondents used charcoal and $1.1 \%$ used firewood. It can be inferred that majority of respondents' sources of energy for cooking was stove which may lead to respiratory diseases and air pollution.

Table 7. Types of drainage facility

Source: Authors' Field Survey, 2012.

\begin{tabular}{lcc}
\hline Type of drainage facility & Frequency & Percentages \\
\hline Open & 176 & 93.1 \\
Closed/covered & 12 & 6.3 \\
Tunnel & 1 & .5 \\
Total & 189 & 100.0 \\
\hline
\end{tabular}

The types of drainage facility available in the study area show that $93.1 \%$ were open drainage, $6.3 \%$ of drainage facility available were closed and only $0.5 \%$ of drainage facility was tunnel types. From this, I can be inferred that the drainage facility available in the study area mainly the open type. The implications of this among others were that, the residents dropped waste inside the drainage, which resulted in the blockage of the drainage. Based on this observation, the study area may likely to be affected by the menace of flood.

Table 8. Methods of waste disposal

\begin{tabular}{lcc}
\hline Methods of waste disposal & Frequency & Percentages \\
\hline Burning & 9 & 4.8 \\
PSP/LAWMA & 116 & 61.4 \\
Open dump site & 18 & 9.5 \\
Cart pusher & 46 & 24.3 \\
Total & 189 & 100.0 \\
\hline
\end{tabular}

Source: Authors' Field Survey, 2012.

The waste generated was disposed by various means in the study area. $4.8 \%$ of respondents disposed their waste through burning system. $61.4 \%$ of respondents disposed their waste through Private Sector Participation/ Lagos State Waste Management Authority( PSP/LAWMA), 9.5\% of respondents disposed waste through open dump site and $24.3 \%$ of respondents disposed waste through cart pursher. This shows the effort of the Lagos state government in waste disposal by the PSP/LAWMA which is very good services regardless of the study area being among slum environment in Lagos state.

Table 9. Frequency of waste disposal

\begin{tabular}{lcc}
\hline Frequency of Waste disposal & Frequency & Percentages \\
\hline Daily & 15 & 7.9 \\
Once in a week & 110 & 58.2 \\
Twice a week & 54 & 28.6 \\
Monthly & 5 & 2.6 \\
Occasionally & 5 & 2.6 \\
Total & 189 & 100.0 \\
\hline
\end{tabular}

Source: Authors' Field Survey, 2012. 
The waste generated was disposed by various means and the frequent rate of disposal is that $7.9 \%$ of respondents disposed their waste daily, $58.2 \%$ of respondents disposed waste twice a week, $2.6 \%$ of respondents disposed waste monthly and occasionally respectively. It is deduced that the activities of PSP/LAWMA is not well appreciated in the study area.

Table 10. Major sources of energy

\begin{tabular}{llc}
\hline Major sources of energy(electricity) & Frequency & Percentages \\
\hline PHCN & 74 & 39.2 \\
Generating set & 114 & 60.3 \\
Inverter & 1 & .5 \\
Total & 189 & 100.0 \\
\hline
\end{tabular}

Source: Authors' Field Survey, 2012.

The major sources of energy in the study area shows that $39.2 \%$ of respondents source of energy is Power Holding Company of Nigeria (PHCN), $60.3 \%$ of respondents major source of energy is generating set and $1 \%$ of respondents source of energy is inverter. It has been deduced that the major source of energy in the study area is generating set which is hazardous to human health.

Table 11. Road conditions

Source: Authors' Field Survey, 2012.

\begin{tabular}{lcc}
\hline Options & Frequency & Percentages \\
\hline Tarred & 49 & 25.9 \\
Untarred & 140 & 74.1 \\
Total & 189 & 100.0 \\
\hline
\end{tabular}

The roads types in the area were either tarred or untarred. $0.25 .9 \%$ of the roads in the study area was tarred while $74.1 \%$ of roads were not tarred (See table 11). This situation can be described as not too good, especially during the raining seasons. This exposes the residents to various dangers such as flooding. In the other hands, during the dry seasons, it generates too much of dust which is very dangerous to human health.

\section{Policy Recommendations}

This study has identified various environmental conditions affecting the lives of slums and shanty dwellers in Nigeria as epitomized in Ijora Badia. The following are some of the policy recommendations of this study.

- In the first instance, there should be a strong and effective method of enforcing environmental policies, particularly in the area of refuse disposal. The Local Government and the Lagos State Waste Management Authorities (LAWMA) are to be reinforced with sufficient funds and equipments for effective functioning, while sanitary inspections are put in place to monitor and arrest the culprits.

- It is equally recommended that essential infrastructure facilities like portable water supply inform of mini-water works or boreholes and public toilets should be provided in strategic places. This will reduce the rate of communicable diseases in the area as well as boosting its physical outlook.

- Provision of good drainages and the maintenance of that drainage should be saddled by the communities and the government to allow for free flow of the drainage to reduce the growing number of mosquitoes.

- The government and non- governmental organization should be able to organized seminar, conferences and the provision of chemicals for the residents in the study area for the proper treatment of their water before drinking, this will reduce the rate of water borne diseases such as diarrhea, dysentery e.t.c.

- All the stakeholders involved in the build environment should see the welfare of the slum dwellers as a collective responsibility in the provision of environmental facility that will make life comfortable for the dwellers.

- In addition, the people need proper enlightenment on the importance and benefits of a healthy environment. This is needful so as to sustain every improvement efforts put in place. For this reason, environmental education should be made compulsory in the school curriculum as well as using public media to educate the 
public particularly the residents of Badia Lagos Nigeria.

\section{References}

Adeola, F. O. (1996). Environmental Hazards, Health and Racial Inequality in Hazardous Waste Distribution. Environmental Behaviour, 2(26), 99.

Brundtland, H. G. (2003). Start New Movement to Address Environmental Crisis Affecting Children's Health.w3.whosea.Org/En/Section260/Section484/Section 484.World Health Day. A paper delivered at the launch of World Health Day; New Delhi, India.

Egunjobi, L. (1986). Human Elements in Urban Planning and Development in Ibadan. Habitat International, 10(44), 147-153. http://dx.doi.org/10.1016/0197-3975(86)90079-2

Expert Group Meeting. (2002). Slum environment in developing countries, meeting held in Nairobi. Retrieved April 7, 2011, from http://www.unhumansettlement.org

Inocent, M. (2009). Slum Development in Cross River, State. Journal of Nigeria Institute of Town Planners, 22(2), 22-24.

Lagos State Economic Summit. (2001). Economic summit on formal and informal economy of Lagos State' held at Eko Hotel July 27-29. Retrieved from http://www.lagosbureau of Statistic on 7/4/2011 at $1.25 \mathrm{am}$

Mabogunje, A. L. (2002). 2002 National Housing and Urban Development Policy: Catalyst for Mass Housing Delivery in Nigeria. Lead Paper Presented at the Second Abuja International Housing Summit Held at the Le Meridien Hotel Abuja.

National Population Commission (NPC). (2006). Census report in Nigeria. Collected from the Lagos State NPC Office Surulere, Nigeria.

National Population Commission of Nigeria Official Web Site. Retrieved from http//www.npcnigeria.org

NDP, (1997). Human Development Report to Eradicate Poverty. Retrieved April 13, 2011, from http://www.unhabitat.org

Onyeche, E. (2011). Ijora Badia: Slum for decades. Retrieved June 17, 2011, from http//www.slumnigeria.org

Smith, K. R., Corvalàn, F. C., \& Kjellström, T. (1999). How much ill health is attributable to environmental factors? Epidemiology, 10(5), 573-584. Retrieved July 17, 2011, from http://www.environmental_health.org http://dx.doi.org/10.1097/00001648-199909000-00027

Tenements Rate Department. (2011). Apapa Local Government, Lagos State, Nigeria.

Tibaijuka, A. (2003). UN Report on slum development across the globe. Retrieved from http://www.unhabital.org on $7 / 4 / 2011$ at $1.30 \mathrm{am}$

UN-Habitat. (2006). State of The World's Cities 2006/2007. The Millennium Development Goals and Urban Sustainability. London, U.K. Retrieved April 13, 2014, from http://www.unhabitat.org

UNICEF. (1999). 'Disposal of sewage where no mains drainage is available...' website. Retrieved July 4, 2011, from http://www.unicef.org

World Bank. (2007). Dhaka, Improving the Living Conditions for the Urban Poor. World Bank Report No. 35824-BD, Washington, D.C. Retrieved May 15, 2011, from http//www.worldbank.org/urban

\section{Copyrights}

Copyright for this article is retained by the author(s), with first publication rights granted to the journal.

This is an open-access article distributed under the terms and conditions of the Creative Commons Attribution license (http://creativecommons.org/licenses/by/3.0/). 